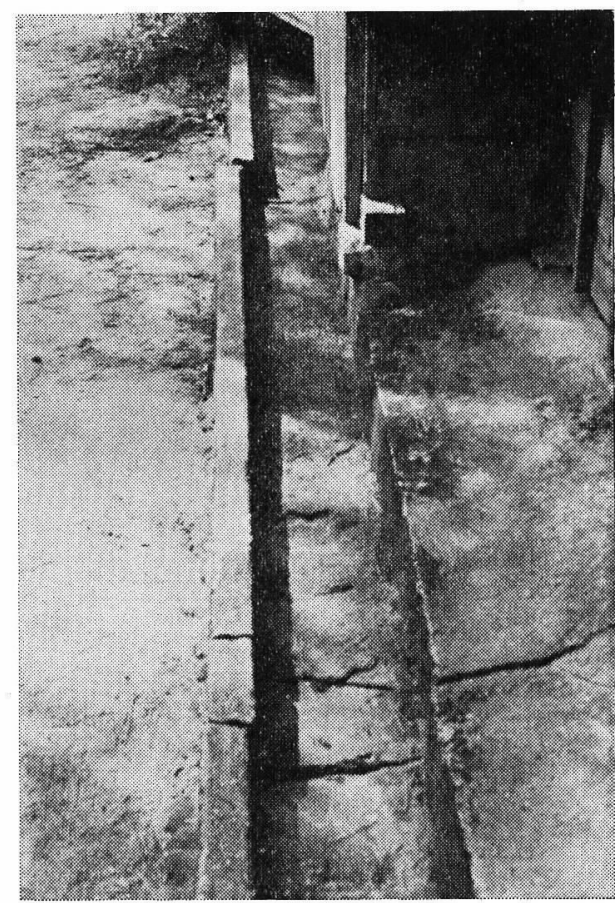

Fig. 2. Picture showing the conjugate faults trace of the earthquake faults. The picture was taken at the place of $\mathrm{P}$ in Fig. 1. These earthquake faults show right-lateral.

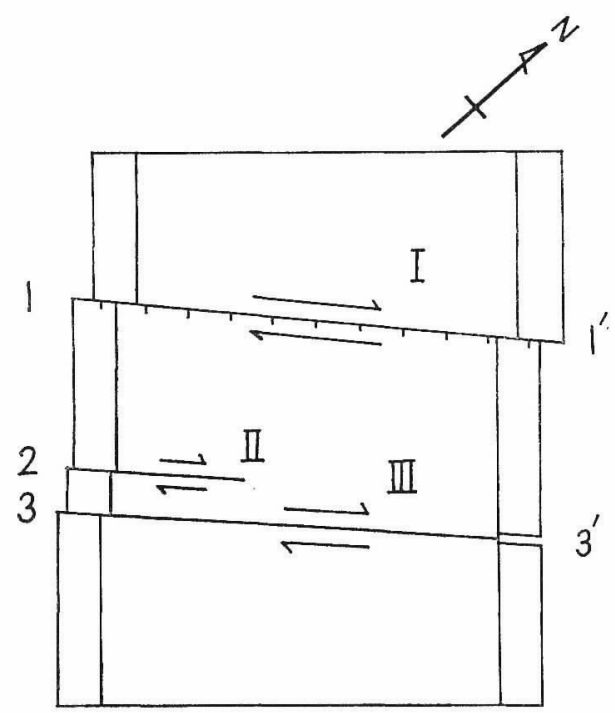

Fig. 3. The earthquake faults associated with the Mikawa earthquake at the Ryūgū Temple. I, II and III show the earthquake faults.
層は, 三河地震主断層で方る深竹炘層の延長部北端 にほぼ直交し， $\mathrm{N} 45^{\circ} \mathrm{E}$ の走向を示し，垂直成分を 持つた右横ずれ断層である。ここに括ける応力場 は，三河地震の初動分布から求めた応力場と同じで ある。

$$
\text { 文献 }
$$

市川政治, 1966, 日本付近の地震のメカニズムに関 する統計的研究と二，三の問題，研究時報，18， 83-154.

飲田汲事・坂部和夫，1972，三河地震汇括仔る深溝 断層の趈長部について，地震 2，25，44-55.

井上宇㳙，1950, 昭和 20 年 1 月 13 日の三河地震 そついて，験震時報，14，49-55.

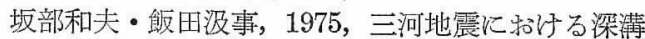
断層の副断層について，地震 $2 ， 28 ， 373-378$. 杉村 新, 1976, 「断層と地震」その歴史と展望, 地質学諭集，12，3-13.

津屋弘洼, 1946, 深淎断層 (昭和 20 年 1 月 13 日 三河地震の際現われた一地震断層)，地震研究所 㪙報，24，59-75.

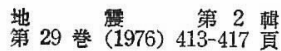

\section{震央付近における震度分 布の異方性}

\author{
京都大学 理学部 \\ 久保寺章
}

福岡教育大学 地学教室

三 浪 俊 夫

(昭和 51 年 10 月 9 日受理)

Anisotropy of Isoseismals near the Epicenter

Akira KUBOTERA

Faculity of Science, Kyoto University

Toshio Mitsunami

Department of Earth Sciences, Fukuoka University of Education

(Received October 9, 1976)

1975 年 1 月の阿蘇カルデラ北部の地震招よび同 年 4 月の大分県中部地震の震度調查を太田裕ら (1974a，b) が作成したアンケート方式による方法 で実施したところ，震英付近の震度分布を示すュン ターは震央を囲んで同心円状とはならず，Fig. 1a， 
2aに見られるようにむしろ細長い楕円に近い形を 示した [久保寺 (1975)，表，他 (1976)]. このよう に震央付近の震度分布に異方性のある例が 2 つ見出 されたが，この棈円形の長軸の方向は地震の際に現 われる特性と種々の点で一致している。ここで「異 方性」といら言葉を用いたが，これが適当か否かは 別として Fig. 1a，2a に見られる震度分布のパター ンを表現する言葉として用いてある.

これら 2 つの地震の場合, 震度分布の長軸の方向 は余震の配列方向, 被害分布, 発震機構図の節面が 地表を切る方向などと良く一致している事が Fig. 1b，1c，2b，2c で確認される [三浪 (1975), 三浪・ 久保寺 (1976), 山科・村井 (1975)]. この 2 つの地 震では，マグニチュードが小さいため断層は地表に 出ていなかつたが，震央付近の震度分布が地款内の 破壊のパターンに支配されていることは明白であ る.

上記 2 例以外に比較的規模の大きい地震で，震度 分布が詳しく知れている地震の例が Table 1 に示し てある. Fig. 3，4，5 の例にも見られるように，震 央付近の震度分布はやはり棈円形であり，その長軸 の方向は地震の諸特性と良く一致している. 震央付 近の震度分布から発震機構の片隣が推定出来そうな ことがこれらの例でわかる.

さて，地震の調査を実施した際，一般の住 民は 震度について最も関心を示す．「震度」は，地震の エネルギーをどれだけ受けたかを指示する量である ため，地震を受ける立場にある住民にとつては関心 が高いのは当然のことと思われる，さらに，地震に ついての諸量のうち人体感覚にたよつて決定される 量であるため, 計測器を持たない住民にとつては唯 一の数量的に決定出来る地震に関する量であること も関心をひく理由の一つかも知れない，震度調査の 有用性については，このように住民の関心度が高い ことも一つの理由であるが，震度調査を実施する側 に立つてみれば，住民一人一人が震度計であつて， しかもそれが非常に密に分布していることが有用性 をより高めているといえるまた，この震度計は非 常に優秀なメモリーを備え持つている.すなわち， 有感地震のあつた時のみメモリーし，しかもこのメ モリーは時間と共に震度の小さいものはどんどん消 去し，最終的には我々が調査を実施したい主な地震 に関するデータのみをメモリーしておいてくれる.

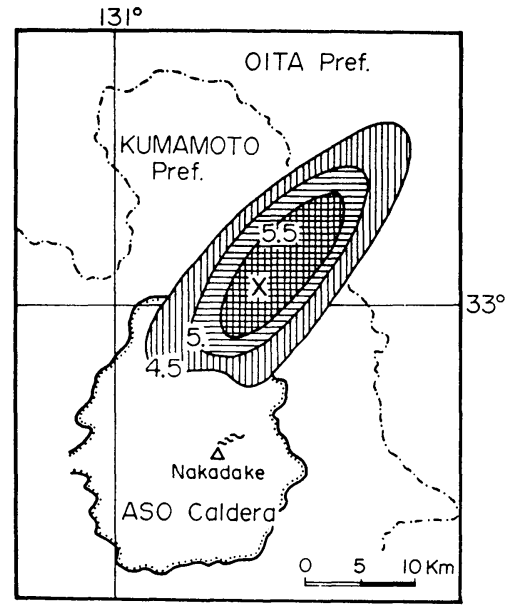

(a)

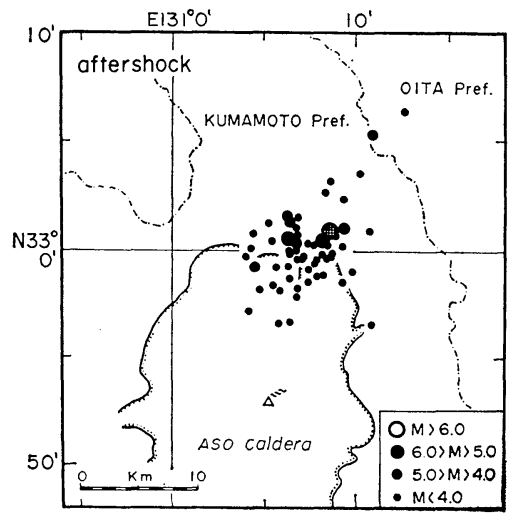

(b)

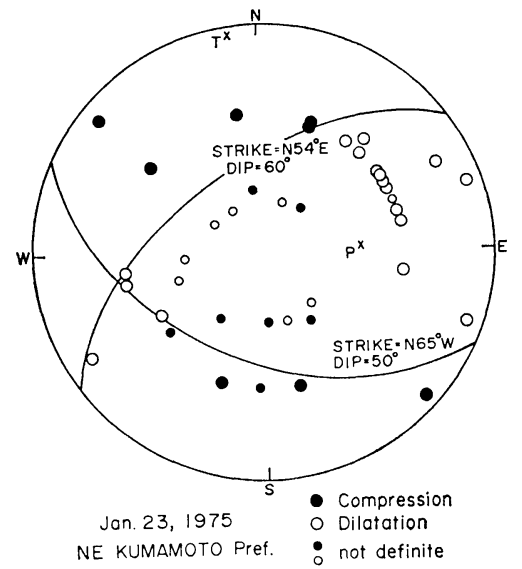

(c)

Fig. 1. a; Map of isoseismals, b; location of epicenters, c; focal mechanism solution of the main shock of the earthquake swarm in the northern part of Aso caldera. 


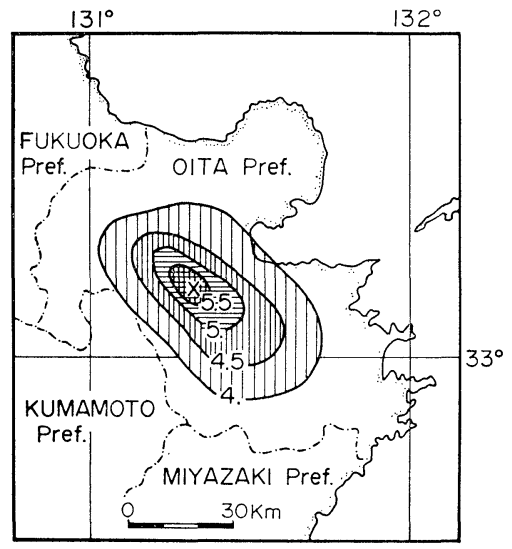

(a)

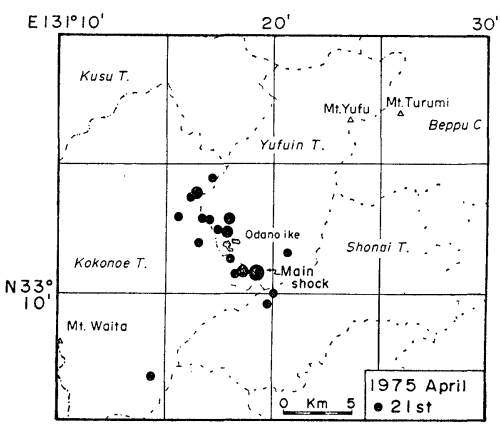

(b)

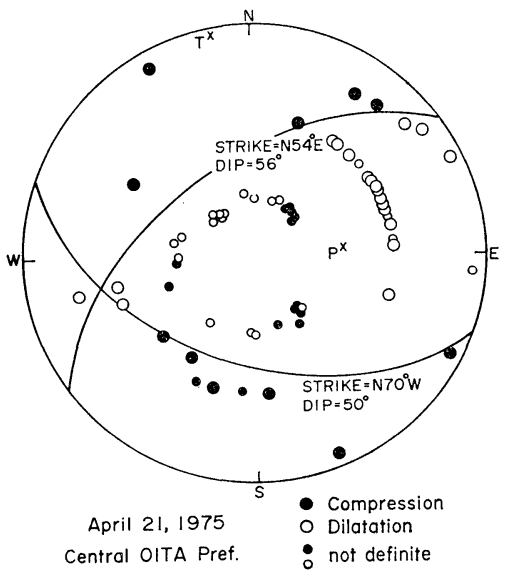

(c)

Fig. 2. a; Map of isoseismals, b; location of epicenters, c ; focal mechanism solution of the earthquake in the central part of Oita prefecture.

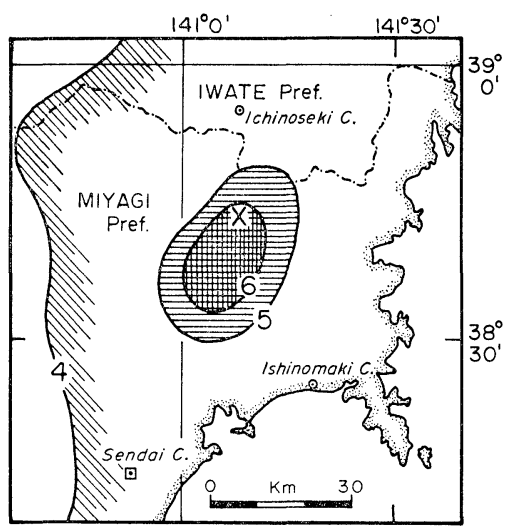

Fig. 3. Map of isoseismals of the earthquake in the central part of Miyagi prefecture.

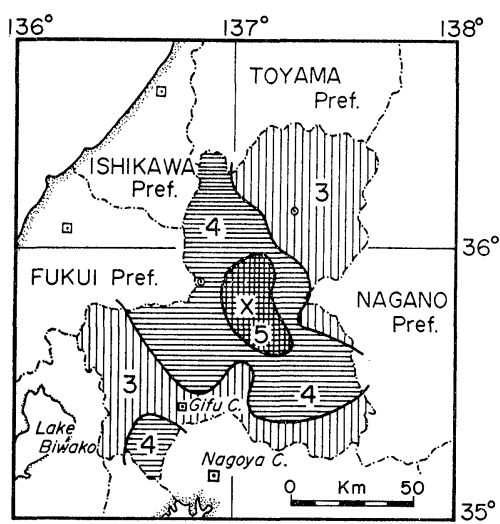

Fig. 4. Map of isoseismals of the earthquake in the central part of Gifu prefecture.

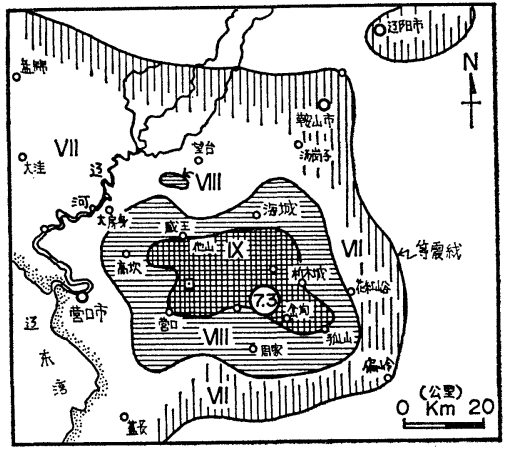

Fig. 5. Map of isoseismals of the earthquake in the northeastern China (Yingkou-Haichéng earthquake). 
Table 1. List of earthquakes which have been observed anisotropic isoseismals.

\begin{tabular}{|c|c|c|c|c|c|c|c|c|}
\hline $\mathrm{Y}$ & M & $\mathrm{D}$ & Lacation & Latitude & Longitude & Depth & M & Remarks \\
\hline 1943 & 8 & 12 & Tajima, Fukushima Pref. & $\mathrm{N} 37.3^{\circ}$ & $\mathrm{E} 139.8^{\circ}$ & 15 & 6.1 & JMA \\
\hline 1959 & 1 & 31 & Teshikaga, Hokkaido & $\mathrm{N} 43.35^{\circ}$ & $\mathrm{E} 140.40^{\circ}$ & 20 & 6.2 & "I \\
\hline & $"$ & & " & $\mathrm{N} 43.45^{\circ}$ & $\mathrm{E} 140.40^{\circ}$ & 0 & 6.1 & " \\
\hline 1961 & 2 & 2 & Nagaoka, Niigata Pref. & $\mathrm{N} 37^{\circ} 27^{\prime}$ & $\mathrm{E} 138^{\circ} 50^{\prime}$ & 20 & 5.2 & $"$ \\
\hline 1962 & 4 & 30 & $\begin{array}{l}\text { Northern part of Miyagi } \\
\text { Pref. }\end{array}$ & $\mathrm{N} 38^{\circ} 44^{\prime}$ & $\mathrm{E} 141^{\circ} 08^{\prime}$ & 0 & 6.5 & " Fig. 3 \\
\hline 1969 & 9 & 9 & Central part of Gifu Pref. & $\mathrm{N} 35^{\circ} 47^{\prime}$ & $\mathrm{E} 137^{\circ} 04^{\prime}$ & 0 & 6.6 & " Fig. 4 \\
\hline 1970 & 10 & 16 & $\begin{array}{l}\text { Southeastern part of } \\
\text { Akita Pref. }\end{array}$ & $\mathrm{N} 39^{\circ} 12^{\prime}$ & $\mathrm{E} 140^{\circ} 45^{\prime}$ & 0 & 6.2 & $"$ \\
\hline 1975 & 1 & 23 & North of Aso caldera & $\mathrm{N} 33^{\circ} 01^{\prime}$ & $\mathrm{E} 131^{\circ} 08^{\prime}$ & 11 & 6.0 & 1) Fig. 1 \\
\hline 1975 & 4 & 21 & Central part of Oita pref. & $\mathrm{N} 33^{\circ} 11^{\prime}$ & $\mathrm{E} 131^{\circ} 19^{\prime}$ & 9 & 6.4 & 2) Fig. 2 \\
\hline 1952 & 7 & 21 & Kern County & $\mathrm{N} 35.0^{\circ}$ & $\mathrm{W} 119.0^{\circ}$ & $\mathbf{s}$ & 7.7 & 3) \\
\hline 1963 & 7 & 26 & Skopje & $\mathrm{N} 42.1^{\circ}$ & $\mathrm{E} 21.5^{\circ}$ & $\mathrm{s}$ & 6.1 & 4) \\
\hline 1967 & 12 & 10 & Koyna & $\mathrm{N} 17^{\circ} 22^{\prime}$ & E $73^{\circ} 45^{\prime}$ & 8 & 6.4 & 5) \\
\hline 1975 & 2 & 4 & Haichéng China & $\mathrm{N} 40^{\circ} 39^{\prime}$ & $\mathrm{E} 122^{\circ} 48^{\prime}$ & 12 & 7.3 & 6) Fig. 5 \\
\hline
\end{tabular}

1) Kubotera, A. (1975), Omote, S., et al. (1976), Neumann, F. and W. K. Cloud(1955), 4) ZAOPeK, A.(1968), 5) GuPta,, et al. (1969), TANDon, A. N., et al. (1968), 6) Xǔ Shào.Xìe (1976)

アンケート方式などの方法を利用すれば，地震に関 する非常に多くの精度の高い情報を与えてくれる。 いかに地震観測の精度が上がり，観測点の分布密度 が高くなつても，震度調査は捨て難い利点を持つて いる.

過去にも, 異常震域の調査から Low Q, High Q などの層の存在が判かり, 過去の地震のマグニチュ 一ドを推定することに利用したりした。 また最近で は，マイクロゾーニングマップを作成して地盤の特 性を知るためにも利用されている．震央付近の震度 の異方性が発震機構とつながりがある点に着目し て，その地震の特性を知ることが出来そうである。 実際, 気象庁の震度階によれば，震度 $\mathrm{V}$; 壁に割れ 目が入り, 墓石, 石どらろらが倒れたり, 煙突, 石 垣などが破損する，震度VI; 家屋の倒壊は $30 \%$ 以 下で山くずれが起き，地割れを生ずる，となつてい る. 震度 $\mathrm{V}$ 以上は破壞現象を伴い，IV以下とは異質 のものである. 震度 $\mathrm{V}$ の程度から震央付近の震度分 布が異方性を示すのも破壞現象を伴らことに原因が あり，最終的には大地の破壞，すなわち発震機構そ のものに直接結びつくように思える.この事は, 観 測体制が充分でない時代の過去の地震について考察
する場合にも利用出来るし，また，現在でも，余震 分布や発震機構の資料がそろうまでに時間がかかる が，震央付近の震度分布のみから地震の拈拈よその 特性を知り，その後の調査方針や観測計画に役立て ることは可能である，震度に関する情報伝達のルー 卜を確保してお活ば，地震後数分でその地震の震央 付近の震度分布は確実につかもことが出来る。

\section{文献}

Gupta, H., H. Narain, B. K. Rastogi and I. MoHan, 1969, A Study of the Koyna Earthquake of December 10, 1967, Bull. Seism. Soc. Amer., 59, 1149-1162.

久保寺章, 1975,1 月 23 日 23 時 19 分の地震 $(M=$ $6.0)$ の震度調査, 1975 年 1 月阿蘇群発地震の活 動之被害に関する調查研究，45-53.

三浪俊夫, 1975，1975 年 1 月の阿蘇カルデラ北部 に発生した地震の震源分布について, 同上, 11-20. 三浪俊夫・久保寺章，1976，大分県中部地震の地震 活動, 1975 年大分県中部地震の活動々被害に関す る調查研究，25-36.

Neumann, F. and W.K. Cloud, 1955, StrongMotion Records of the Kern County Earthquakes, Earthquakes in Kern County, California Durring 1952, 205-210.

太田 裕・後藤典俊， $1974 \mathrm{a} ，$ アンケートによる道 
内各地の震度の推定と Seismic Microzoning Map の作成の試み, 1973 年 6 月 17 日根室半島沖地 震調查報告, 302-325.

太田 裕・後藤典俊, $1974 \mathrm{~b}$, アンケートによる震 度の推定および Seismic Microzoning Map の作 成の試み一1973 年根室半島沖地震を例として一, 自然災害資料解析, $1,14-24$.

表俊一郎, 他, 1976, 大分県中部地震のアンヶート 方式による震度調査解析, 1976年大分県中部地震 の活動と被害に関する調査研究報告, $25-36$.

Tandon, A. N. and H. M. Chaundhury, 1968, Koyna Earthquake of December, 1967, India Meteorological Dep., Scientific Rep., 59.
許紹 旻 (Xu Shào-Xìe), 1976, 海城地震活動の特 徵, 中国地震考察団講演論文集, 27-41.

山科健一郎・村井 勇，1975，1975年大分県中部地 震・阿蘇北部地震のメカニズムについて，とくに 活断層々の関係, 震研畚報, 50, 295-302.

ZATOPEK, A., 1968, The Skopje Earthquake of July 1963 and the Seismicityot Macedonia, The Skopje Earthquake of 26 July 1963, 89129.

ZAToPeK, A., 1968, The Skopje Earthquake of July 1963 and the Seismicity Mecedonia, The Skopje Earthquake of 26 July 1663, 89-129. 